\title{
Synthesis, Spectroscopic Characterization, Molecular Docking, and Evaluation of Antibacterial Potential of Transition Metal Complexes Obtained Using Triazole Chelating Ligand
}

\author{
Najlaa S. Al-Radadi $\left({ }^{D},{ }^{1}\right.$ Ehab M.Zayed, ${ }^{2}$ Gehad G. Mohamed, ${ }^{3,4}$ and Hayam A. Abd El Salam ${ }^{2}$ \\ ${ }^{1}$ Department of Chemistry, Faculty of Science, Taibah University, Al-Madinah Al-Monawara 14177, \\ P. O. Box 30002, Saudi Arabia \\ ${ }^{2}$ Department of Green Chemistry, National Research Centre, Dokki, Giza 12622, Egypt \\ ${ }^{3}$ Department of Chemistry, Faculty of Science, Cairo University, Giza 12613, Egypt \\ ${ }^{4}$ Egypt Nanotechnology Center, Cairo University, El-Sheikh Zayed, 6th October 12588, Giza, Egypt
}

Correspondence should be addressed to Najlaa S. Al-Radadi; nsa@taibahu.edu.sa

Received 26 September 2019; Revised 19 December 2019; Accepted 14 January 2020; Published 24 February 2020

Academic Editor: Radhey Srivastava

Copyright (c) 2020 Najlaa S. Al-Radadi et al. This is an open access article distributed under the Creative Commons Attribution License, which permits unrestricted use, distribution, and reproduction in any medium, provided the original work is properly cited.

\begin{abstract}
Mononuclear chelates of $\mathrm{Ni}(\mathrm{II}), \mathrm{Co}(\mathrm{II}), \mathrm{Fe}(\mathrm{III}), \mathrm{Cd}(\mathrm{II})$, and $\mathrm{Cu}(\mathrm{II})$ derived from triazole novel tridentate ligands were prepared and characterized by different spectroscopic methods. The metal to ligand ratio was $1: 2$, which was revealed by elemental analysis. All the complexes were electrolytic in nature as suggested by the conductivity measurements. IR pointed out that the coordination of the triazole ligand toward the metal ions was carried out through $\mathrm{N}$ amino and $\mathrm{S}$ thiophenolic atoms. The complexes were found to have octahedral geometry, and their thermal stability was also studied. The XRD spectrum of $\mathrm{Co}$ (II) and Fe(III) complexes concluded their crystalline structure. The parent ligand and its chelates were investigated for antimicrobial potential. Bioassay of all triazole complexes showed increased activity as compared to that of the ligand. The complexes having $\mathrm{Ni}(\mathrm{II}), \mathrm{Co}(\mathrm{II})$, and $\mathrm{Cu}(\mathrm{II})$ ions as metal center exhibited superior antibacterial activity in opposition to Gram-positive (B. subtilis and S. pyogenes) and Gram-negative (E. coli and P. vulgaris) bacterium as compared to standard.
\end{abstract}

\section{Introduction}

The complexes exhibiting photoluminescence acquire much attention and interest, being utilized for different applications including biological probes, oxygen sensors, and phosphorescent dopants in optoelectronic apparatus $[1,2]$. In modern coordination chemistry, compounds which have cyclic imines are of great importance in forming stable complexes with some transition metal ions $[3,4]$. Triazole compounds with some transition metals showed significant antibacterial, antitumor, and antifungal activity besides effective antiviral agents [5-8]. We find the metal complexes of ligands which have S,N-heterocycles promising for enhanced biological activities compared to the native ligand [9]. The preparation of metal complexes containing 1,2,4-triazole ligands has good application in recent years [10-14]. A lot of transition metal complexes of 1,2,4-triazoles substituted can be prepared [15]. The 1,2,4-triazoles have been explored for linking ligands among transition metal ions. The target for the linking can be from first $\mathrm{N}$ to second $\mathrm{N}$ (N1 to N2) atoms. In recent years, preparing coordination ligands using 1,2,4-triazole moiety acquired great attention [16]. A variety of derivatives of 1,2,4-triazole in addition to its own complexes was reported as an excellent compound for constructing many metal coordination polymers [17-21]. Fatty acids containing nitrogen derivatives have good attention recently because of their high biological activity [22].

From the above discussion and mentioned facts, our idea was to enhance access to pharmacologically interesting 
complexes depending on their derivatives with selected metallic cations considered as important feed stocks for the chemical industry with promise of potential advance. In present study we discuss the preparation, characterization, and antibacterial study relating to $\mathrm{Ni}(\mathrm{II}), \mathrm{Cu}(\mathrm{II}), \mathrm{Fe}(\mathrm{III})$, $\mathrm{Cd}(\mathrm{II})$, and $\mathrm{Co}(\mathrm{II})$ complexes of 4-amino-5-stearyl-1,2,4triazole-3-thiol (HL). In the current work, the synthesis of bidentate triazole ligand and its monomeric metal complexes in the company relating to $\mathrm{Cd}(\mathrm{II}), \mathrm{Co}(\mathrm{II}), \mathrm{Fe}(\mathrm{III})$, $\mathrm{Cu}(\mathrm{II})$, and $\mathrm{Ni}(\mathrm{II})$ ions is demonstrated. The synthesized complexes were analyzed through state-of-the-art physicochemical techniques including NMR, IR, and EDS and screened for antibacterial potential against some pathogenic species.

\section{Materials and Methods}

All analytical grade reagents having utmost purity were utilized in this work. The ranges of chemicals were $\mathrm{CuCl}_{2} \cdot 2 \mathrm{H}_{2} \mathrm{O}$ procured from Sigma; $\mathrm{COCl}_{2} \cdot 6 \mathrm{H}_{2} \mathrm{O}$, $\mathrm{CdCl}_{2} \cdot 2 \mathrm{H}_{2} \mathrm{O}$, and $\mathrm{NiCl}_{2} \cdot 6 \mathrm{H}_{2} \mathrm{O}$ from $\mathrm{BDH}$; and $\mathrm{FeCl}_{3} \cdot 6 \mathrm{H}_{2} \mathrm{O}$ from Prolabo. The organic solvents were absolute ethyl alcohol and dimethylformamide (DMF), and they were observed spectroscopically and cleaned using BDH. Every preparation was made in double-distilled water.

2.1. Instrumentation. A Jenway 4010 conductivity meter was utilized to record the molar conductance of solid chelates in DMF, while the solid reflectance spectra were recorded using a Shimadzu 3101pc spectrophotometer.

Extensive ${ }^{\mathrm{l}} \mathrm{H}-\mathrm{NMR}$ spectra beginning 0 to $15 \mathrm{ppm}$ recorded on Varian-Oxford Mercury were operated at $300 \mathrm{MHz}$. The samples for ${ }^{1} \mathrm{H}-\mathrm{NMR}$ spectra were prepared in DMSod6 (deuterated dimethylsulfoxide). For powder XRD analysis, BV XRD spectrometer from Philips Analytical type PW 1840 controlled at $40 \mathrm{kV}$ plus $25 \mathrm{~mA}$ applying $2000 \mathrm{~W}$ radiation via copper anode was used. Faraday method was applied for molar magnetic susceptibility analysis of powdered samples. Pascal's constant diamagnetic corrections were done while calibrations were performed using $\mathrm{Hg}$ $\left[\mathrm{Co}(\mathrm{SCN})_{4}\right]$. FTIR spectrum was taken among $4000-200 \mathrm{~cm}^{-1}$ using PerkinElmer FTIR type 1650 spectrophotometer by preparing $\mathrm{KBr}$ pellets.

CHNS-932 (LECO) Vario elemental analyzer was used to analyze the separated solid chelates in duplicate for presence of $\mathrm{C}, \mathrm{H}, \mathrm{N}, \mathrm{S}$, and $\mathrm{Cl}$ at Microanalytical Center, Cairo University.

Mass spectra were taken on MS-5988 GS-MS HP spectrometer controlled on $70 \mathrm{eV}$ via EI technique at Microanalytical Center, Cairo University. Considering thermal analyses (TG, DTG, and DTA) Shimadzu TG-60 H simultaneous DTA-TG apparatus was used in dynamic nitrogen $\left(20 \mathrm{~mL} \cdot \mathrm{min}^{-1}\right)$ atmosphere having $10^{\circ} \mathrm{C} \cdot \mathrm{min}^{-1}$ rate of heating.

2.2. Metal Complexes Synthesis. To a solution of the triazole ligand $(0.3 \mathrm{~g}, 0.847 \mathrm{mM})$ in ethanol $\left(30 \mathrm{~cm}^{3}\right)$, a solution containing metal (II)/(III) chloride $(0.847 \mathrm{mM})$ in ethanol $\left(15 \mathrm{~cm}^{3}\right)$ was added. Mixed solution was refluxed using a water bath as long as $3 \mathrm{~h}$ whereupon the complexes were going to precipitate. The collected precipitate was filtered, clean washing was done using ethanol and diethyl ether, and it was vacuum-dried for later experiments.

2.3. $\left[\mathrm{Cu}(\mathrm{HL})_{2}\left(\mathrm{H}_{2} \mathrm{O}\right)_{2}\right] \mathrm{Cl}_{2}$. Yield $75 \%$; brown solid, Anal. Calcd. for $\mathrm{C}_{38} \mathrm{H}_{80} \mathrm{Cl}_{2} \mathrm{CuN}_{8} \mathrm{O}_{2} \mathrm{~S}_{2}$ (\%): C, $51.90 ; \mathrm{H}, 8.85 ; \mathrm{N}$, 12.88; S, 6.95; Cu, 6.75. Found (\%): C, 51.88; H, 9.17; N, 12.74; S, 7.29; M, 7.22. IR $\left(\nu, \mathrm{cm}^{-1}\right): 2755 \mathrm{sh}(\mathrm{C}-\mathrm{SH}), 1630 \mathrm{sh}$ $\left(\mathrm{N}-\mathrm{NH}_{2}\right), 830$ sh coordinated $\mathrm{H}_{2} \mathrm{O}, 566 \mathrm{~s}(\mathrm{Cu}-\mathrm{O}), 447 \mathrm{~s}(\mathrm{Cu}-$ $\mathrm{N}), 430 \mathrm{~s}(\mathrm{Cu}-\mathrm{S})$.

2.4. $\left[\mathrm{Cd}(\mathrm{HL})_{2}\left(\mathrm{H}_{2} \mathrm{O}\right)_{2}\right] \mathrm{Cl}_{2}$. Yield $85 \%$; dark green, Anal. Calcd. for $\mathrm{C}_{38} \mathrm{H}_{80} \mathrm{CdCl}_{2} \mathrm{~N}_{8} \mathrm{O}_{2} \mathrm{~S}_{2}$ (\%): C, 48.88; $\mathrm{H}, 8.23 ; \mathrm{N}$, 12.45; S, 6.55; Cu, 11.76. Found (\%): C, 49.15; H, 8.68; N, 12.07; S, 6.91; M, 12.11. IR $\left(\nu, \mathrm{cm}^{-1}\right): 2770 \mathrm{sh}(\mathrm{C}-\mathrm{SH}), 1634 \mathrm{sh}$ (N-NH$), 740 \mathrm{~s}$ coordinated $\mathrm{H}_{2} \mathrm{O}, 565 \mathrm{~s}(\mathrm{Cd}-\mathrm{O}), 465 \mathrm{w}$ (CdN), 438 s (Cd-S).

2.5. $\left[\mathrm{Fe}(\mathrm{HL})_{2}\left(\mathrm{H}_{2} \mathrm{O}\right)_{2}\right] \mathrm{Cl}_{3}$. Yield $87 \%$; green, Anal. Calcd. for $\mathrm{C}_{38} \mathrm{H}_{80} \mathrm{FeCl}_{3} \mathrm{~N}_{8} \mathrm{O}_{2} \mathrm{~S}_{2}$ (\%): C, 50.13; H, 8.63; N, 11.54; S, 6.62; Fe, 5.86. Found (\%): C, 50.30; H, 8.89; N, 12.35; S, 7.07; M, 6.15. IR $\left(\nu, \mathrm{cm}^{-1}\right)$ : $2730 \mathrm{sh}(\mathrm{C}-\mathrm{SH}), 1640 \mathrm{~s}\left(\mathrm{~N}-\mathrm{NH}_{2}\right), 766 \mathrm{sh}$ coordinated $\mathrm{H}_{2} \mathrm{O}, 560 \mathrm{~s}(\mathrm{Fe}-\mathrm{O}), 525 \mathrm{~s}(\mathrm{Fe}-\mathrm{N}), 462 \mathrm{w}(\mathrm{Fe}-\mathrm{S})$.

2.6. $\left[\mathrm{Ni}(\mathrm{HL})_{2}\left(\mathrm{H}_{2} \mathrm{O}\right)_{2}\right] \mathrm{Cl}_{2}$. Yield 82\%; pale brown, Anal. Calcd. for $\mathrm{C}_{38} \mathrm{H}_{80} \mathrm{NiCl}_{2} \mathrm{~N}_{8} \mathrm{O}_{2} \mathrm{~S}_{2}$ (\%): C, 51.69; $\mathrm{H}, 8.88 ; \mathrm{N}$, 13.71; S, 6.90; Ni, 6.45. Found (\%): C, 52.17; H, 9.22; N, 12.81; S, 7.33; Ni, 6.71. IR $\left(\nu, \mathrm{cm}^{-1}\right)$ : $2780 \mathrm{sh}(\mathrm{C}-\mathrm{SH}), 1625 \mathrm{sh}(\mathrm{N}-$ $\mathrm{NH}_{2}$ ), $835 \mathrm{w}$ coordinated $\mathrm{H}_{2} \mathrm{O}, 580 \mathrm{~s}(\mathrm{Ni}-\mathrm{O}), 530 \mathrm{~s}(\mathrm{Ni}-\mathrm{N})$, 446 sh (Ni-S).

2.7. $\left[\mathrm{Co}(\mathrm{HL})_{2}\left(\mathrm{H}_{2} \mathrm{O}\right)_{2}\right] \mathrm{Cl}_{2}$. Yield $63 \%$; dark blue, Anal. Calcd. for $\mathrm{C}_{38} \mathrm{H}_{80} \mathrm{CoCl}_{2} \mathrm{~N}_{8} \mathrm{O}_{2} \mathrm{~S}_{2}$ (\%): C, 51.79; $\mathrm{H}, 9.13 ; \mathrm{N}, 12.46 ; \mathrm{S}$, 7.12; Ni, 6.58. Found (\%): C, 52.16; H, 9.21; N, 12.81; S, 7.33; Co, 6.73. IR $\left(\nu, \mathrm{cm}^{-1}\right)$ : 2760sh (C-SH), 1650 br $\left(\mathrm{N}^{-\mathrm{NH}_{2}}\right)$, $835 \mathrm{~s}$ coordinated $\mathrm{H}_{2} \mathrm{O}, 575 \mathrm{~m}(\mathrm{Co}-\mathrm{O}), 490 \mathrm{~s}(\mathrm{Co}-\mathrm{N}), 427 \mathrm{w}$ (Co-S).

2.8. Molecular Modeling Methodology. The optimized structural geometry of the triazole ligand was identified using Gaussian 09 software by applying DFT/B3LYP process having range of base sets [23]. The Gaussian files obtained through this method were visualized using GaussView molecular visualization program [24]. They were calculated by using HOMO-LUMO energies; the DFT/ B3LYP quantum chemical parameter was calculated in accordance with the numerical pattern appearing in gas phase in the view of the compounds. Additionally, the other parameters of optimized structures such as considerable bond lengths, excitation energies, oscillator strengths, and efficient charges required for coordinating functional groups were figured out. 
TABLe 1: Elemental and physical data of triazole ligand and its metal complexes.

\begin{tabular}{|c|c|c|c|c|c|c|c|}
\hline \multirow{2}{*}{ Compound } & \multicolumn{5}{|c|}{$\%$ found (calcd.) } & \multirow{2}{*}{$\mu_{\mathrm{eff}}(\mathrm{B} . \mathrm{M})$} & \multirow{2}{*}{$\Lambda_{\mathrm{m}} \Omega^{-1} \cdot \mathrm{mol}^{-1} \cdot \mathrm{cm}^{2}$} \\
\hline & $\mathrm{C}$ & $\mathrm{H}$ & $\mathrm{N}$ & $\mathrm{S}$ & $\mathrm{M}$ & & \\
\hline $\mathrm{HL}$ & $64.12(64.33)$ & $10.45(10.80)$ & $15.58(15.80)$ & $8.75(9.04)$ & & & \\
\hline$\left[\mathrm{Fe}(\mathrm{HL})_{2}\left(\mathrm{H}_{2} \mathrm{O}\right)_{2}\right] \mathrm{Cl}_{3}$ & $50.13(50.30)$ & $8.63(8.83)$ & $11.54(12.36)$ & $6.62(7.06)$ & $5.86(6.18)$ & 92.20 & 92.20 \\
\hline$\left[\mathrm{Co}(\mathrm{HL})_{2}\left(\mathrm{H}_{2} \mathrm{O}\right)_{2}\right] \mathrm{Cl}_{2}$ & $51.79(52.17)$ & $9.13(9.15)$ & $12.46(12.81)$ & $7.12(7.32)$ & $6.58(6.75)$ & 5.30 & 130 \\
\hline$\left[\mathrm{Ni}(\mathrm{HL})_{2}\left(\mathrm{H}_{2} \mathrm{O}\right)_{2}\right] \mathrm{Cl}_{2}$ & $51.69(52.17)$ & $8.88(9.15)$ & $13.71(12.81)$ & $6.90(7.32)$ & $6.45(6.75)$ & 3.60 & 120 \\
\hline$\left[\mathrm{Cu}(\mathrm{HL})_{2}\left(\mathrm{H}_{2} \mathrm{O}\right)_{2}\right] \mathrm{Cl}_{2}$ & $51.90(51.91)$ & $8.85(9.11)$ & $12.88(12.75)$ & $6.95(7.29)$ & $6.75(7.23)$ & 1.70 & 43.10 \\
\hline$\left[\mathrm{Cd}(\mathrm{HL})_{2}\left(\mathrm{H}_{2} \mathrm{O}\right)_{2}\right] \mathrm{Cl}_{2}$ & $48.88(49.19)$ & $8.23(8.63)$ & $12.45(12.08)$ & $6.55(6.90)$ & $11.76(12.08)$ & Diama & 124 \\
\hline
\end{tabular}

2.9. Molecular Docking. Docking computations were performed using AutoDock tools 4.2 by applying Gasteiger partial charges incorporated into the designed drug (ligand) atoms. Depending on the protein-ligand interaction pattern, the calculations were carried out. Hydrogen atoms with nonpolar nature were conjoined, and bonds which can be rotatable were clarified. Subsequent to the incorporation of fundamental hydrogen atoms, Kollman unified atom style charges, and salvation factors, the AutoDock tools were pertained $[25,26]$. Electrostatic and van der Waals terms were determined using distance dependent dielectric functions and AutoDock parameter set, respectively. For simulative docking, Lamarckian genetic algorithm and Solis and Wets local search methodology were applied [27]. Incidentally, properties of the ligand molecule like torsions, primary position, and orientation were positioned. The entire rotatable torsions were excluded throughout docking experiment. Ten diverse runs were performed for every docking experiment, which was positioned toward block subsequent to decisive 250,000 energy assessments while the size was set up to 150 . During the experiment, torsion and translational step of 5 and $0.2 \AA$ were utilized, respectively.

2.10. Biological Activity. The biological activity of triazole and its corresponding chelates was evaluated using agar well diffusion method against B. subtilis (ATCC6635), S. pyogenes (ATCC443) $\left(\mathrm{Gram}^{+}\right)$; E. coli (ATCC25922), P. vulgaris(ATCC33420) $\left(\mathrm{Gram}^{-}\right)$bacterium. Total $500 \mu \mathrm{L}$ spore solution with $10^{-6}-10^{-7}$ spores $\mathrm{mL}^{-1}$ concentration was inoculated very soon prior to solidification for every examined organism in sterilized agar preceded with pouring into sterile Petri dishes, having $45 \mathrm{~mm}$ radius, later permitted for solidification. Then, a sterile cork borer with $3 \mathrm{~mm}$ radius was utilized for creating three wells at different locations to every agar solidified Petri dish. To each well, $100 \mathrm{mg} \cdot \mathrm{mL}^{-1}$ experimental compounds were mixed with DMF poured in the sterile Petri plates and then allowed for $48 \mathrm{~h}$ incubation on $37^{\circ} \mathrm{C}$. The control was prepared using $0.1 \mathrm{~mL} \mathrm{DMF}$ at the same conditions. The zone of inhibition was calculated for control and experimental Petri dish containing metal complexes or free triazole ligand. For determination of antibacterial activity of these compounds, the experiment was performed in triplicate. The $\mathrm{IC}_{50}$ (the lowest concentration of compound capable of inhibiting 50\% growth) was calculated from MIC measurements.

\section{Results and Discussion}

The elemental analyses of the triazole-thiol and its monomeric chelates were determined, showed good support with the proposed structures of the ligand and its chelates, and have been reported in Table 1.

3.1. Infrared Spectral Analysis of Triazole Ligand and Complexes. IR spectrum of ligand showed an intense signal at $2820 \mathrm{~cm}^{-1}$ pointing out the presence of thiophenolic group $(-\mathrm{SH})$. This sharp signal was shifted in the spectra of complexes $\left(2730-2780 \mathrm{~cm}^{-1}\right)$, indicting that the thiophenolic - $\mathrm{SH}$ group still protonated and was involved in coordination with metal ions [28]. The ligand showed an intense band due to stretching vibrations of amino group at $3200-3240 \mathrm{~cm}^{-1}$. This band was embedded within the $-\mathrm{OH}$ stretching vibration of coordinated water molecules at $3250-3500 \mathrm{~cm}^{-1}$. The bending vibration of the amino group at $1608 \mathrm{~cm}^{-1}$ was observed consistently with the amino absorption of free triazole ligand [29]. This latter peak was transferred to $1625-1650 \mathrm{~cm}^{-1}$ for spectra of metal chelates, confirming the coordination of amino group to metal ions [29].

Besides the above bands, the IR bands, due to triazole ring systems between 1520 and $1566 \mathrm{~cm}^{-1}$ which are almost unaffected in the complexes, have been assigned to $\mathrm{C}=\mathrm{N}$. These facts were further confirmed by occurrence of some new signals $(\mathrm{M}-\mathrm{N})$ at $447-530 \mathrm{~cm}^{-1}, \quad(\mathrm{M}-\mathrm{S})$ at $427-462 \mathrm{~cm}^{-1}$, and $(\mathrm{M}-\mathrm{O})$ at $565-580 \mathrm{~cm}^{-1}$ in the spectra of complexes $[29,30]$. Bands at $745-780 \mathrm{~cm}^{-1}$ may be attributed to rocking and wagging modes of the coordinated water. It was concluded from the significant shift of free ligand $\left(\mathrm{NH}_{2}\right)$ to lower wave number side, with increased wave number for thiophenolic (C-S) stretching band in complexes, that bonding of the ligand to metal ion is through thiophenolic sulfur and amino nitrogen.

3.2. ${ }^{l} H$ NMR Analysis of Ligand and Its Monomeric Complexes. ${ }^{1} \mathrm{H}$ NMR spectra of ligand in DMSO exhibited a singlet at $\delta=13.34 \mathrm{ppm}$ for thiophenolic $-\mathrm{SH}$, singlet at $\delta=5.45 \mathrm{ppm}$ due to $\mathrm{NH}_{2}$ group, multiplets in the region $\delta=1.19-2.46 \mathrm{ppm}$ due to $-\mathrm{CH}_{2}$ groups, and $\mathrm{CH}_{3}$ singlet at $\delta=0.82 \mathrm{ppm} .{ }^{1} \mathrm{H}$ NMR spectrum of $\mathrm{Cd}(\mathrm{II})$ complex in DMSO showed small intensity peak at $\delta=13.34 \mathrm{ppm}$ corresponding to the presence of thiophenolic $-\mathrm{SH}$, thus indicating remaining of hydrogen and coordination of ligand to metal through thiophenolic $\mathrm{SH}$ group. This finding 
TAвLE 2: Thermoanalytical results (TG and DTG) of triazole ligand and its metal complexes.

\begin{tabular}{|c|c|c|c|c|c|c|c|}
\hline Compound & $\begin{array}{c}\text { TG range } \\
\left({ }^{\circ} \mathrm{C}\right)\end{array}$ & $\begin{array}{l}\mathrm{DTG}_{\max } \\
\left({ }^{\circ} \mathrm{C}\right)\end{array}$ & $n^{*}$ & $\begin{array}{l}\text { Mass loss total } \\
\text { mass loss calcd } \\
(\text { estim }) \% \\
\end{array}$ & Assignment & Residue & DTA $\left({ }^{\circ} \mathrm{C}\right)$ \\
\hline \multirow[b]{2}{*}{$\mathrm{HL}$} & $24-200$ & 162,181 & 2 & \multirow{2}{*}{$\begin{array}{c}28.24(29.47) \\
71.77(70.54) 100.1 \\
(100.1) \\
\end{array}$} & \multirow{2}{*}{$\begin{array}{l}\text { (i) Loss of } \mathrm{C}_{7} \mathrm{H}_{16} \\
\text { (ii) Loss of } \mathrm{C}_{12} \\
\mathrm{H}_{22} \mathrm{~N}_{4} \mathrm{~S}\end{array}$} & \multirow[b]{2}{*}{ - } & \multirow{2}{*}{$\begin{array}{c}60(-), 72(+), 99(-), 110(+) \\
186(-), 219(-)\end{array}$} \\
\hline & $200-325$ & 204,237 & 2 & & & & \\
\hline \multirow[b]{2}{*}[\mathrm{Fe}(\mathrm{HL})_{2}(\mathrm{H}_{2}\mathrm{O})_{2}]{$\mathrm{Cl}_{3}$} & $25-300$ & 267 & 1 & $50.91(51.44)$ & $\begin{array}{l}\text { (i) Loss of } 3 \mathrm{HCl} \\
\text { and } \mathrm{C}_{25} \mathrm{H}_{54}\end{array}$ & \multirow[b]{2}{*}{$1 / 2 \mathrm{Fe}_{2} \mathrm{O}_{3}$} & \multirow{2}{*}{$\begin{array}{c}55(-), 67(+), 152(-), 235(+) \\
280(+), 500(-), 688(-) \\
711(-)\end{array}$} \\
\hline & $300-780$ & 381,573 & 2 & $\begin{array}{c}40.49(39.73) 91.40 \\
(91.17)\end{array}$ & $\begin{array}{l}\text { (ii) Loss of } \\
0.5\left(\mathrm{H}_{2} \mathrm{O}\right) \\
\mathrm{C}_{13} \mathrm{H}_{25} \mathrm{~N}_{8} \mathrm{~S}_{2}\end{array}$ & & \\
\hline \multirow{3}{*}[\mathrm{Co}(\mathrm{HL})_{2}(\mathrm{H}_{2}\mathrm{O})_{2}]{$\mathrm{Cl}_{2}$} & $25-250$ & 150 & 1 & $15.67(15.16)$ & $\begin{array}{l}\text { (i) Loss of } 2 \mathrm{HCl} \text {, } \\
\mathrm{CH}_{4} \text {, and } \mathrm{C}_{3} \mathrm{H}_{9}\end{array}$ & \multirow{3}{*}{$\mathrm{CoO}$} & \multirow{3}{*}{$\begin{array}{l}80(+), 176(-), 199(-) \\
263(-), 350(+), 415(-)\end{array}$} \\
\hline & $250-400$ & 359 & 1 & $33.75(33.28)$ & $\begin{array}{l}\text { (ii) Loss of } \mathrm{H}_{2} \mathrm{O} \text { and } \\
\mathrm{C}_{20} \mathrm{H}_{37}\end{array}$ & & \\
\hline & $400-680$ & 410 & 1 & $\begin{array}{c}44.62 \text { (43.98) } 94.04 \\
(92.42)\end{array}$ & $\begin{array}{l}\text { (iii) Loss of } \\
\mathrm{C}_{14} \mathrm{H}_{30} \mathrm{~N}_{8} \mathrm{~S}_{2}\end{array}$ & & \\
\hline \multirow{4}{*}[\mathrm{Ni}(\mathrm{HL})_{2}(\mathrm{H}_{2}\mathrm{O})_{2}]{$\mathrm{Cl}_{2}$} & $25-200$ & 58 & 1 & $18.33(18.93)$ & \multirow{4}{*}{$\begin{array}{l}\text { (i) Loss of } 2 \mathrm{HCl} \text {, } \\
\mathrm{CH}_{4} \text {, and } \mathrm{C}_{5} \mathrm{H}_{13} \\
\text { (ii) Loss of } \mathrm{C}_{12} \mathrm{H}_{25} \\
\text { (iii) Loss of } \mathrm{H}_{2} \mathrm{O} \\
\text { and } \mathrm{C}_{7} \mathrm{H}_{11} \\
\text { (iv) Loss of } \\
\mathrm{C}_{13} \mathrm{H}_{23} \mathrm{~N}_{8} \mathrm{~S}_{2}\end{array}$} & \multirow{4}{*}{$\mathrm{NiO}$} & \multirow{4}{*}{$\begin{array}{c}40(-), 63(+), 115(-), 125(+) \\
208(-), 286(-), 345(-), \\
370(+), 415(-)\end{array}$} \\
\hline & $200-250$ & 241 & 1 & $19.82(19.28)$ & & & \\
\hline & $250-350$ & 287 & 1 & $12.95(13.36)$ & & & \\
\hline & $350-600$ & 363 & 1 & $\begin{array}{c}41.60(39.95) 92.70 \\
(91.52)\end{array}$ & & & \\
\hline \multirow{3}{*}[\mathrm{Cu}(\mathrm{HL})_{2}(\mathrm{H}_{2}\mathrm{O})_{2}]{$\mathrm{Cl}_{2}$} & $25-150$ & 73,110 & 2 & $10.36(9.04)$ & $\begin{array}{c}\text { (i) Loss of } \mathrm{CH}_{4} \text { and } \\
2 \mathrm{HCl}\end{array}$ & \multirow{3}{*}{$\mathrm{CuO}$} & \multirow{3}{*}{$\begin{array}{c}81(+), 95(-), 114(+), 237(-) \\
273(+), 369(-), 399(+)\end{array}$} \\
\hline & $150-350$ & 541 & 1 & $51.11(51.49)$ & $\begin{array}{l}\text { (ii) Loss of } \mathrm{H}_{2} \mathrm{O} \text { and } \\
\mathrm{C}_{31} \mathrm{H}_{61}\end{array}$ & & \\
\hline & $350-650$ & 393 & 1 & $\begin{array}{c}29.71(30.35) 91.85 \\
(90.88)\end{array}$ & $\begin{array}{l}\text { (iii) Loss of } \\
\mathrm{C}_{6} \mathrm{H}_{13} \mathrm{~N}_{8} \mathrm{~S}_{2}\end{array}$ & & \\
\hline \multirow{4}{*}[\mathrm{Cd}(\mathrm{HL})_{2}(\mathrm{H}_{2}\mathrm{O})_{2}]{$\mathrm{Cl}_{2}$} & $25-250$ & 233 & 1 & $20.01(22.47)$ & $\begin{array}{l}\text { (i) Loss of } \mathrm{CH}_{4} \text {, } \\
2 \mathrm{HCl} \text {, and } \mathrm{C}_{8} \mathrm{H}_{19}\end{array}$ & \multirow{4}{*}{$\mathrm{CdO}$} & \multirow{4}{*}{$\begin{array}{c}100(+), 234(-), 306(+) \\
456(+), 523(+)\end{array}$} \\
\hline & $250-400$ & 311 & 1 & $18.12(17.43)$ & $\begin{array}{l}\text { (ii) Loss of } \mathrm{H}_{2} \mathrm{O} \text { and } \\
\mathrm{C}_{11} \mathrm{H}_{18}\end{array}$ & & \\
\hline & $400-500$ & 442 & 1 & $9.06(9.01)$ & (iii) Loss of $\mathrm{C}_{6} \mathrm{H}_{12}$ & & \\
\hline & $500-800$ & 630 & 1 & $\begin{array}{c}37.43(37.31) 84.62 \\
(86.22)\end{array}$ & $\begin{array}{l}\text { (iv) Loss of } \\
\mathrm{C}_{12} \mathrm{H}_{27} \mathrm{~N}_{8} \mathrm{~S}_{2}\end{array}$ & & \\
\hline
\end{tabular}

confirmed the IR data. The peak due to $\mathrm{NH}_{2}$ group was found in the $\mathrm{Cd}(\mathrm{II})$ complex at $5.35 \mathrm{ppm}$. This shift confirmed the participation of $\mathrm{NH}_{2}$ in coordination with the metal ions. Peaks corresponding to $-\mathrm{CH}_{3}$ and $-\mathrm{CH}_{2}$ groups are also present in spectrum of Cd(II) complex without any change. Retention of peaks without any formal change indicated the preservation of the formal structure of ligand without any deformation [31].

3.3. Molar Conductance Study. The molar conductance values measured in DMF solution were found to be 43.10 , 130, 124, 120, and $92.20 \Omega^{-1} \cdot \mathrm{mol}^{-1} \mathrm{~cm}^{2}$ for $\mathrm{Cu}(\mathrm{II}), \mathrm{Co}(\mathrm{II})$, $\mathrm{Cd}(\mathrm{II}), \mathrm{Ni}(\mathrm{II})$, and $\mathrm{Fe}(\mathrm{III})$ complexes, respectively. Respective molar conductance values confirmed that the complexes were electrolytes [32].

3.4. Thermogravimetric Analysis. For determination of the general scheme for thermal decomposition of chelates and evaluation of the presence of water molecule either inside or outside the central metal ion, thermogravimetric analysis (TG, DTG, and DTA) was performed.
This analysis also helped to determine the thermal stability of the new synthesized complexes. By controlling conditions such as temperature starting from atmospheric temperature to $\sim 1000^{\circ} \mathrm{C}$ under $\mathrm{N}_{2}$ gas and controlling the heating rates properly on $10^{\circ} \mathrm{C} \mathrm{min}^{-1}$, weight loss was calculated. Thermogravimetric and DTA data are provided in Table 2 .

The TG curves of Fe(III) and $\mathrm{Co}$ (II) chelates pointed out the first step decomposition around $25-300$ and $25-250^{\circ} \mathrm{C}$ with $51.44 \%$ mass loss (calculated $50.91 \%$ ) and 15.16 mass loss (calculated 15.67\%), indicating the loss of $3 \mathrm{HCl}$ and $\mathrm{C}_{25} \mathrm{H}_{54}$, and $2 \mathrm{HCl}, \mathrm{CH}_{4}$, and $\mathrm{C}_{3} \mathrm{H}_{9}$ molecules, respectively. The $\mathrm{Fe}(\mathrm{III})$ and $\mathrm{Co}(\mathrm{II})$ complexes showed weight loss of $39.73 \%$ (calculated $40.49 \%$ ) and $78.37 \%$ (calculated $77.26 \%$ ) at temperature ranges of $300-780$ and $250-680^{\circ} \mathrm{C}$, which correspond to the removal of remaining ligand molecules, respectively.

A weight loss of $18.93 \%$ (calculated $18.33 \%$ ) was observed in the TG curve of $\mathrm{Ni}$ (II) complex in 25 and $200^{\circ} \mathrm{C}$ temperature range which suggested elimination about $2 \mathrm{HC} 1, \mathrm{CH}_{4}$, and part of the organic ligand $\left(\mathrm{C}_{5} \mathrm{H}_{13}\right)$. The weight losses of $72.59 \%$ (calculated $74.37 \%$ ) at temperature 
range $200-600^{\circ} \mathrm{C}$ corresponded to the removal of the remaining ligand molecules.

Similarly at a temperature of $25-150^{\circ} \mathrm{C}$ and $25-250^{\circ} \mathrm{C}$, $\mathrm{CH}_{4}$ and $2 \mathrm{HCl}$ or $\mathrm{CH}_{4}, 2 \mathrm{HCl}$, and $\mathrm{C}_{8} \mathrm{H}_{19}$ moieties were eliminated corresponding to a weight loss of $9.04 \%$ (calculated $10.36 \%$ ) and $22.47 \%$ (calculated $20.01 \%$ ) for $\mathrm{Cu}(\mathrm{II}$ ) and $\mathrm{Cd}(\mathrm{II})$ complexes, respectively. The remaining ligand molecules were eliminated in the subsequent steps and the decomposition was completed at $\sim 650$ and $800^{\circ} \mathrm{C}$ leading to the formation of the stable metal oxide $\mathrm{CuO}$ and $\mathrm{CdO}$.

The DTA data listed in Table 2 pointed out that the decomposition of the ligand and its metal complexes appeared as exothermic and endothermic peaks.

3.5. Magnetic Moment Analysis and Electronic Spectra. The subtle reflectance spectra for Fe(III) complex indicated a signal at $21,362 \mathrm{~cm}^{-1}$, possibly specified toward ${ }^{6} \mathrm{~A}_{\mathrm{lg}} \longrightarrow \mathrm{T}_{2 \mathrm{~g}}$ $(\mathrm{G})$ conversion into octahedral geometry belonging to complex [33-35]. The transition ${ }^{6} \mathrm{~A}_{1 \mathrm{~g}} \longrightarrow{ }^{4} \mathrm{~T}_{2 \mathrm{~g}}(\mathrm{G})$ and ${ }^{6} \mathrm{~A}_{1 \mathrm{~g}} \longrightarrow{ }^{4} \mathrm{~T}_{1} \mathrm{~g}$ was split into two signals at 17,642 and $12,784 \mathrm{~cm}^{-1}$. The $\mathrm{Fe}(\mathrm{III})$ complex has magnetic moment 5.30 B.M. Therefore, the produced complex showed octahedral geometry indicating $\mathrm{d}^{2} \mathrm{sp}^{3}$ hybridization of $\mathrm{Fe}(\mathrm{III})$ [35], while in case of $\mathrm{Cu}$ (II) complex broad band was observed at $15,921 \mathrm{~cm}^{-1}$. This signal was generally perfectly symmetric with an octahedral geometry designed for $\mathrm{Cu}$ (II) complex. The value of 1.70 B.M from magnetic moment pinpointed the octahedral structure [36].

The Co(II) complex spectrum of diffused reflectance showed three signals at $13,215,15,841$, and $17,492 \mathrm{~cm}^{-1}$. The octahedral geometry was supported by the value of the magnetic moment of the complex $\left(\mu_{\text {eff }}=5.06\right.$ B.M.) [36]. The spectrum reflectance of $\mathrm{Ni}(\mathrm{II})$ complex also showed three spectral peaks at $21,645,17,377$, and $13,542 \mathrm{~cm}^{-1}$. The locations of all three peaks were clearly harmonic by those portended in favor of octahedral geometry [35]. These bands can be assigned, respectively [36], to ${ }^{3} \mathrm{~A}_{2 \mathrm{~g}}(\mathrm{~F}) \longrightarrow{ }^{3} \mathrm{~T}_{\mathrm{lg}}(\mathrm{F})$, ${ }^{3} \mathrm{~A}_{2 \mathrm{~g}}(\mathrm{~F}) \longrightarrow{ }^{3} \mathrm{~T}_{2 \mathrm{~g}}(\mathrm{P})$, and ${ }^{3} \mathrm{~A}_{2 \mathrm{~g}}(\mathrm{~F}) \longrightarrow{ }^{3} \mathrm{~T}_{2 \mathrm{~g}}(\mathrm{~F})$ conversion. Octahedral geometry can be additionally supported by the magnetic moment value $\mu_{\text {eff }}=3.30$ B.M. The empirical formula of $\mathrm{Cd}$ (II) complex indicated that it has diamagnetic and octahedral geometry properties [36].

3.6. Mass Spectral (MS) Studies. The mass spectra of the ligands $\mathrm{Ni}(\mathrm{II}), \mathrm{Cd}(\mathrm{II})$, and $\mathrm{Co}(\mathrm{II})$ chelates exhibited molecular ion $\mathrm{m} / \mathrm{z}$ bands at $354,876,928$, and 880 atomic mass unit, which were in accordance with the molecular weights proposed, 354, 874, 928, and $878.5 \mathrm{amu}$, respectively. The molecular weights of the ligand and metal chelates agreed with elemental and thermogravimetric analyses, which have been utilized to prove the suggested formula. These prove the stoichiometry of complexes as we suggested in this type $\left[\mathrm{M}(\mathrm{Hl})_{2}\right]$. The multipeak type of the spectrum mass indicated the nature of the sequent degradation of base compound having peaks' series identical to a variety of fractions. The intensity of peaks provides an insight about stability of fragments. The fragmentation pattern of free ligand is shown in Scheme 1.
3.7. X-Ray Diffraction Analysis (Powder-XRD). The synthesized $\mathrm{Fe}(\mathrm{III})$ and $\mathrm{Co}(\mathrm{II})$ complexes were found to have a crystalline character $[37,38]$.

3.7.1. Structural Interpretation. Depending on the range of spectral and physicochemical analysis presented here, the structures of ligand and its metal complexes are shown in Figures 1 and 2 .

\subsection{Molecular Modeling}

3.8.1. Molecular Parameters. Additional parameters such as chemical potentials $(P i)$, absolute electronegativities $(\chi)$, global softness $(S)$, absolute hardness $(\eta)$, additional electronic charge $\left(\Delta N_{\max }\right)$, global electrophilicity $(\omega)$, and absolute softness $(\sigma)$ estimated for the $\mathrm{Hl}$ free ligand are listed in Supplementary Table 1. The toxicity and the reactivity of various selective sites could be described by electrophilicity index $(\omega)$, which is considered as significant quantum chemical headline. The biological activity of drug-receptor interaction may be quantified by the electrophilicity. Also, the stabilization energy was determined by this index when the system was obtained from the environment on an additional negative charge. The $\eta$ and $\sigma$ parameters are scheme of the molecular reactivity and stability, and their perceptions were linked with all others. The softness index was on the contrary to global stiffness. The suggested structures were supported by these parameters, and the mentioned quantum chemical parameters were studied through the recommended equations [39-41]. The calculated data are presented in Supplementary Table 1, and the following study able to illustrate that

(i) The information of HL ligand indicated an enormous possibility in favor of biological action based on elevated $\omega$ value.

(ii) $\eta$ is hardness, whereas $S$ and $\omega$ were indexes for softness; as the energy difference between EHOMO and ELUMO increasing the stability of the molecule increases (Figure 3). Therefore, the reactive soft molecule is having pliable contribution to metal ions. Thus, the explored HL ligand was observed soft against coordination.

(iii) It was clear from the negative electronic chemical potential $(\mu)$ value and the positive electrophilicity index $(\chi)$ value that the HL ligand has a negative electronic chemical potential due to accepting electrons from the environment, which leads to decrease in its energy [42].

(iv) The overall energy for the liberated ligand observed was very tiny, which clearly signified that the isolated ligands were stable.

(v) The very tiny energy space may be related to low kinetic stability, reflecting efficient electronic charge transfer interaction and high chemical reactivity, making the ligand strongly polarizable. 


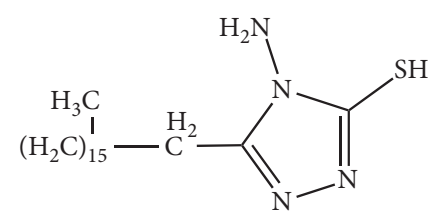

4-amino-5-heptadecyl-4H-1,2,4-triazole-3-thiol

Chemical formula: $\mathrm{C}_{19} \mathrm{H}_{38} \mathrm{~N}_{4} \mathrm{~S}$

Exact mass:354.28

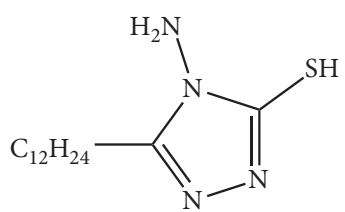

Molecular weight: 283.46

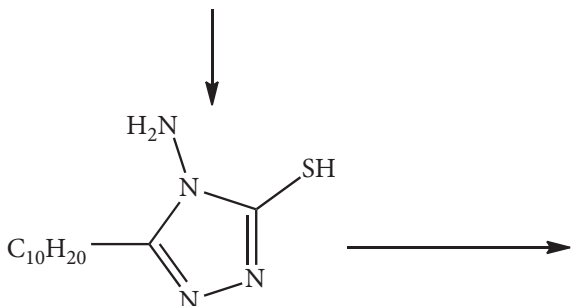

Molecular weight: 255.40

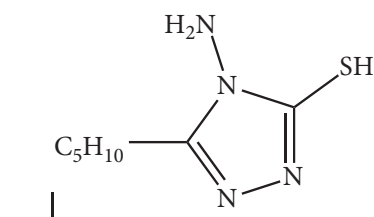

Molecular weight: 185.27

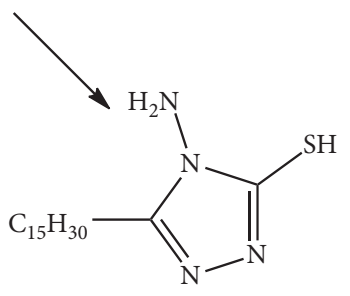

Molecular weight: 325.54

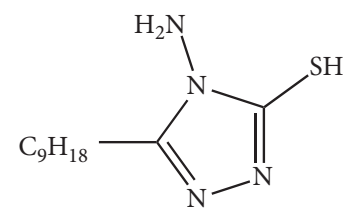

Molecular weight: 241.38

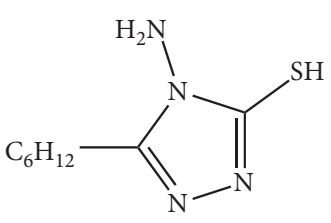

Molecular weight: 199.30<smiles>Cc1nnc(S)n1N</smiles>

Molecular weight: 129.16<smiles>Cc1nnc(S)n1N</smiles>

Molecular weight: 116.14

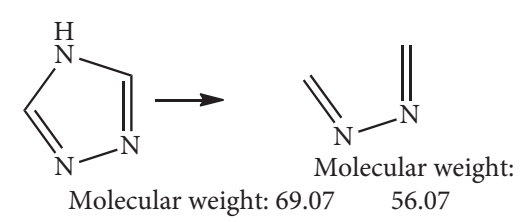

SCHEMe 1

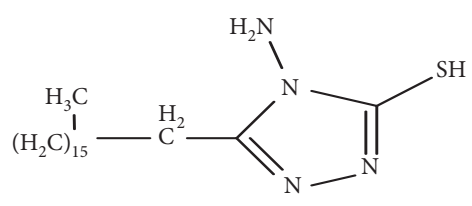

4-amino-5-heptadecyl-4H-1,2,4-triazole-3-thiol

FIGURE 1: Proposed structure of triazole ligand.

3.8.2. The Atomic Charges, Bond Angles, and Bond Lengths. The calculation of atomic charges played a significant role in the application of quantum mechanical calculations $[42,43]$. The estimated atomic charge was determined by Mulliken population analysis with optimized geometry and the data

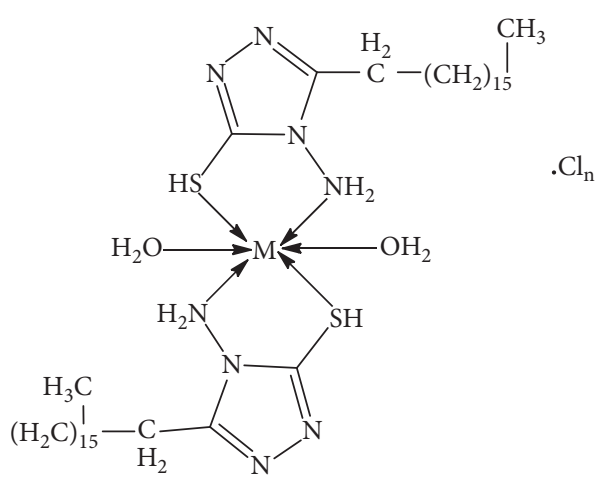

Figure 2: Proposed structure of complexes. 

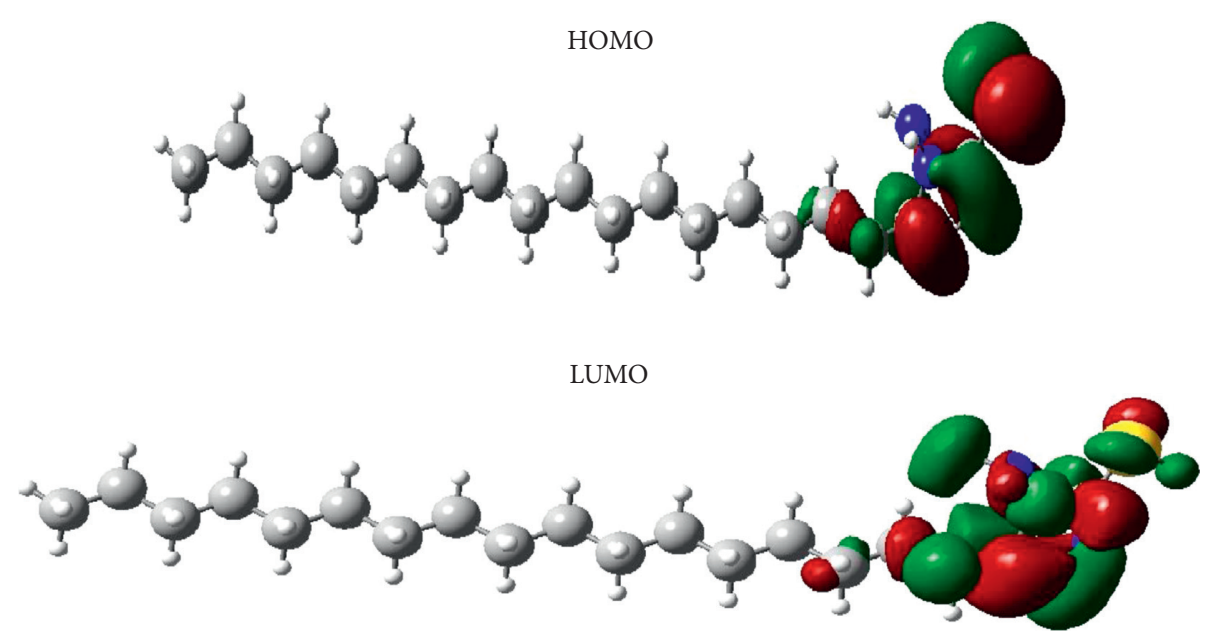

FIgURE 3: HOMO and LUMO patterns of triazole ligand.

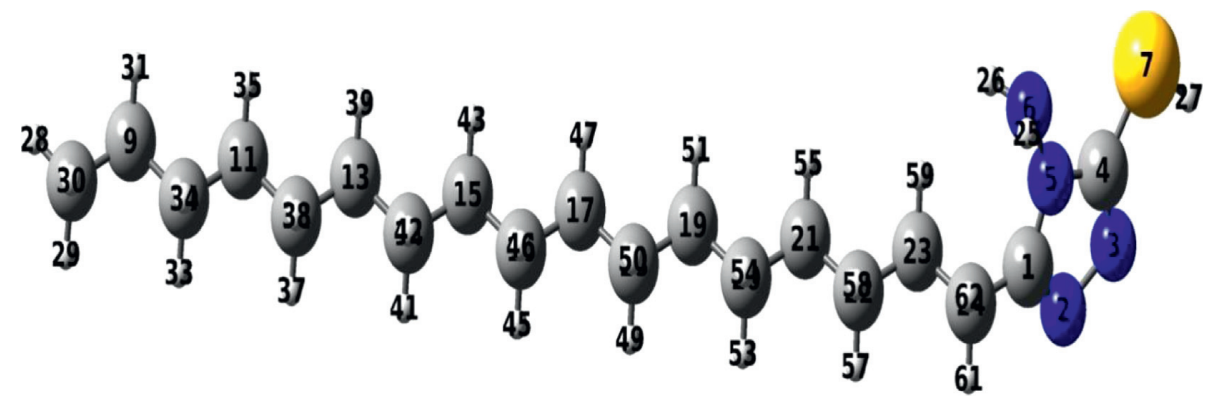

Figure 4: Numbering system for triazole ligand.

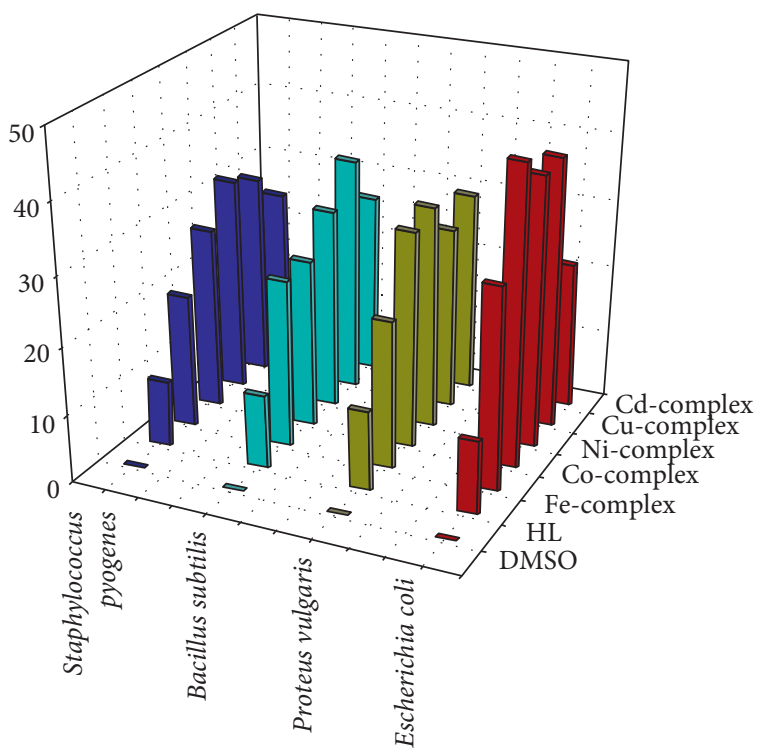

Figure 5: Biological activity of triazole ligand and its metal complexes.

are listed in Supplementary Tables 2 and 3 and is shown in Figure 4. Since noticed, the N(II) and N(III) atoms have lower negative atomic charges compared to nitrogen atoms (N6) from the amino group, and also the existence of $\mathrm{N} 2$ and $\mathrm{N} 3$ beside and attached to N6 and S7 causes higher electronegativity, and from that these atoms were suggested as center of chelation. Results listed in Supplementary Tables 2 and 3 indicated that sulfur (S7) and amino nitrogen $\mathrm{N} 6$ atoms in $\mathrm{Hl}$ have extra negative charges compared to other atoms.

The suitable places of coordination with metal ions were predicted using Mulliken method existent of triazole ligand HL that was additionally carried through MEP analysis. On the other hand, the bond of (Cl-C24) had more length than the other bonds in triazole ring $(\mathrm{N} 2, \mathrm{~N} 3)$, $(\mathrm{N} 3, \mathrm{C} 4)$, and $(\mathrm{C} 4, \mathrm{~N} 5)$; the large bond length of $(\mathrm{C} 4, \mathrm{~S} 7)$ and $(\mathrm{N} 5, \mathrm{~N} 6)$; and the big bond angle (N3,C4,S7), (Cl,N5,N6), $(\mathrm{C} 4, \mathrm{~N} 5, \mathrm{~N} 6)$, and $(\mathrm{N} 2, \mathrm{C} 1, \mathrm{C} 24)$, Supplementary Tables (2, $3)$. Also, the high dihedral bond angles (N3,C4,N5,N6), $(\mathrm{S} 7, \mathrm{C} 4, \mathrm{~N} 5, \mathrm{C} 1), \quad(\mathrm{S} 7, \mathrm{C} 4, \mathrm{~N} 5, \mathrm{~N} 6), \quad(\mathrm{N} 3, \mathrm{C} 4, \mathrm{~S} 7, \mathrm{H} 27)$, (N5,C4,S7,H27), (Cl,N5,N6,H25), (Cl,N5,N6,H26), (C4,N5,N6,H25), (C4,N5,N6,H26), (C24,C1,N5,C4), (C24,C1,N5,N6), (N2,C1,C24,C23), (N2,C1,C24,H61), (N2,C1,C24,H62), (N5,C1,C24,C23), (N5,C1,C24,H61), (N5,C1,C24,H62), (N2,N3,C4,S7), and (C24,C1,N2,N3) enhanced the rapture of these bonds firstly, Supplementary Tables 2 and 3. This suggestion was compatible with mass fragmentation and thermal degradation and confirmed the discussion.

3.8.3. Antimicrobial Activity of Ligand and Its Monomeric Complexes. Synthesized triazole and its corresponding 
TABLE 3: Biological activity of triazole ligand and its metal chelates.

\begin{tabular}{lcccc}
\hline \multicolumn{2}{l}{ Sample } & \multicolumn{2}{c}{ Inhibition zone (mm sample) } \\
& Escherichia coli & Proteus vulgaris & Bacillus subtilis & Sram positive \\
& 0 & 0 & 0 & 0 \\
Control: DMSO & 11 & 12 & 11 & 10 \\
$\mathrm{HL}$ & 30 & 22 & 25 & 20 \\
{$\left[\mathrm{Fe}(\mathrm{HL})_{2}\left(\mathrm{H}_{2} \mathrm{O}\right)_{2}\right] \cdot \mathrm{Cl}_{3}$} & 44 & 32 & 25 & 27 \\
{$\left[\mathrm{Co}(\mathrm{HL})_{2}\left(\mathrm{H}_{2} \mathrm{O}\right)_{2}\right] \cdot \mathrm{Cl}_{2}$} & 40 & 33 & 30 & 32 \\
{$\left[\mathrm{Ni}(\mathrm{HL})_{2}\left(\mathrm{H}_{2} \mathrm{O}\right)_{2}\right] \cdot \mathrm{Cl}_{2}$} & 40 & 27 & 35 & 30 \\
{$\left[\mathrm{Cu}(\mathrm{HL})_{2}\left(\mathrm{H}_{2} \mathrm{O}\right)_{2}\right] \cdot \mathrm{Cl}_{2}$} & 22 & 30 & 27 & 25 \\
{$\left[\mathrm{Cd}(\mathrm{HL})_{2}\left(\mathrm{H}_{2} \mathrm{O}\right)_{2}\right] \cdot \mathrm{Cl}_{2}$} & 7 & 6 & 7 & 8 \\
Amikacin & & & & 25 \\
\hline
\end{tabular}
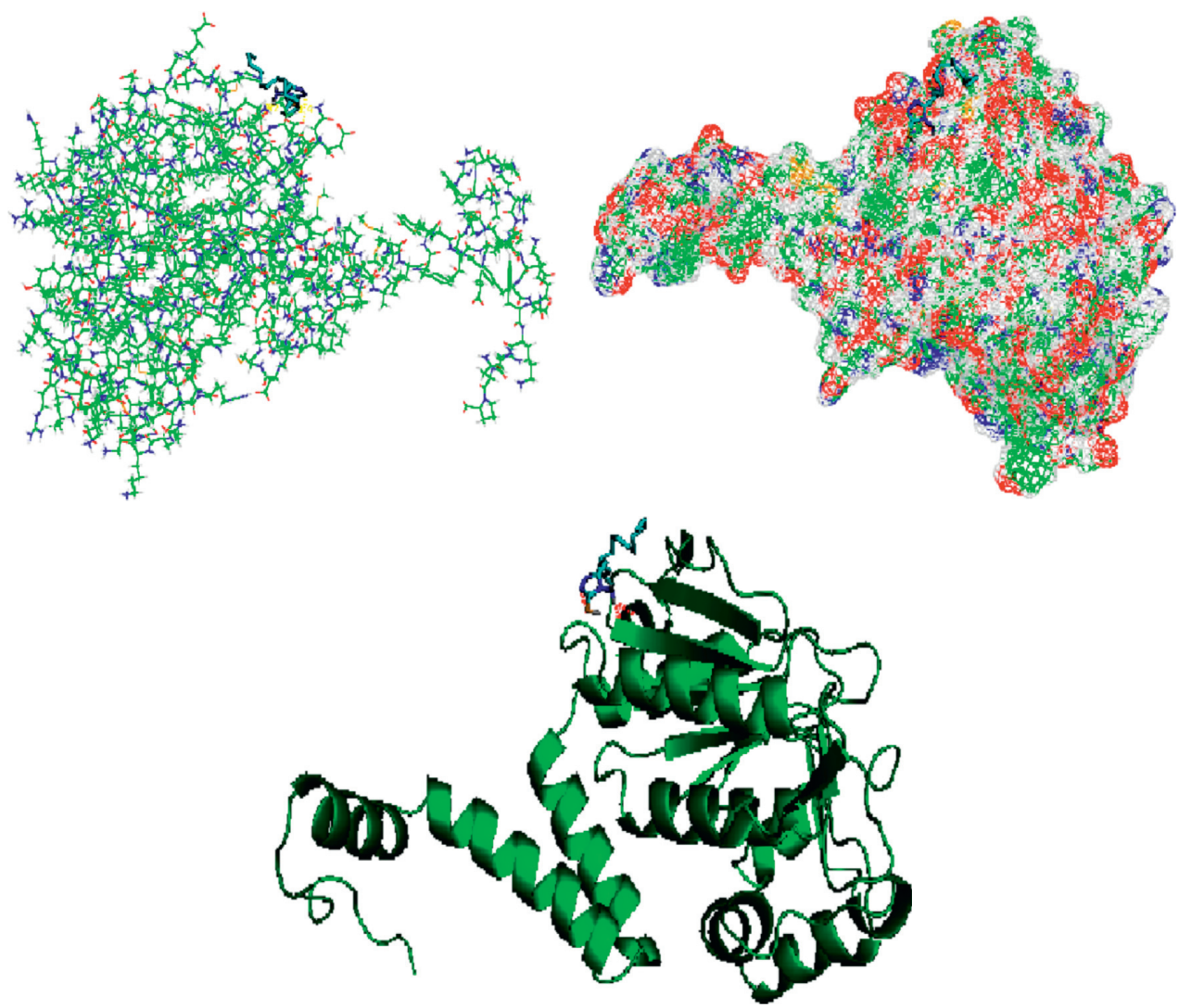

Figure 6: Three-dimensional plot of interaction of triazole ligand with E. coli (3 t88) receptor.

metal chelates were investigated against Bacillus subtilis, Proteus vulgaris, Escherichia coli, and Staphylococcus pyogenes to estimate their potential as antimicrobial agents by well-diffusion method, which is well known as the agar ditch method. An observed zone of inhibition is shown in Figure 5. The counted zones of inhibition next to the growth of respective microorganisms are listed in Table 3. It was observed from Table 3 that all complexes showed greater antibacterial activity than that of ligand [44]. All the complexes showed very good results against all bacterial strains. Furthermore, metal complexes showed excellent antibacterial activity against $E$. coli. In addition, $\mathrm{Cd}(\mathrm{II}), \mathrm{Ni}(\mathrm{II})$, and $\mathrm{Co}$ (II) chelates have very good antibacterial activity toward P. vulgaris, while $\mathrm{Ni}(\mathrm{II})$ and $\mathrm{Cu}(\mathrm{II})$ complexes showed high antibacterial activity against $B$. subtilis and $S$. pyogenes organisms Figure 5.

The zone of inhibition can be monitored by altering the incubation conditions, culture medium, concentration of the antibacterial agent, and rate of diffusion. The activity of all the synthesized complexes may be demonstrated according to the chelation theory where the polarity of the metal atom decreased by chelation. This reduction in polarity is due to partial share of the $\pi$ electron delocalization and positive charge of the donor groups of the coordination sphere (Figure 5). Also, the lipophilic nature of the central atom increased by chelation, serving its penetration to the lipid layer of the cell membrane [45]. The main aim of this work was to utilize 

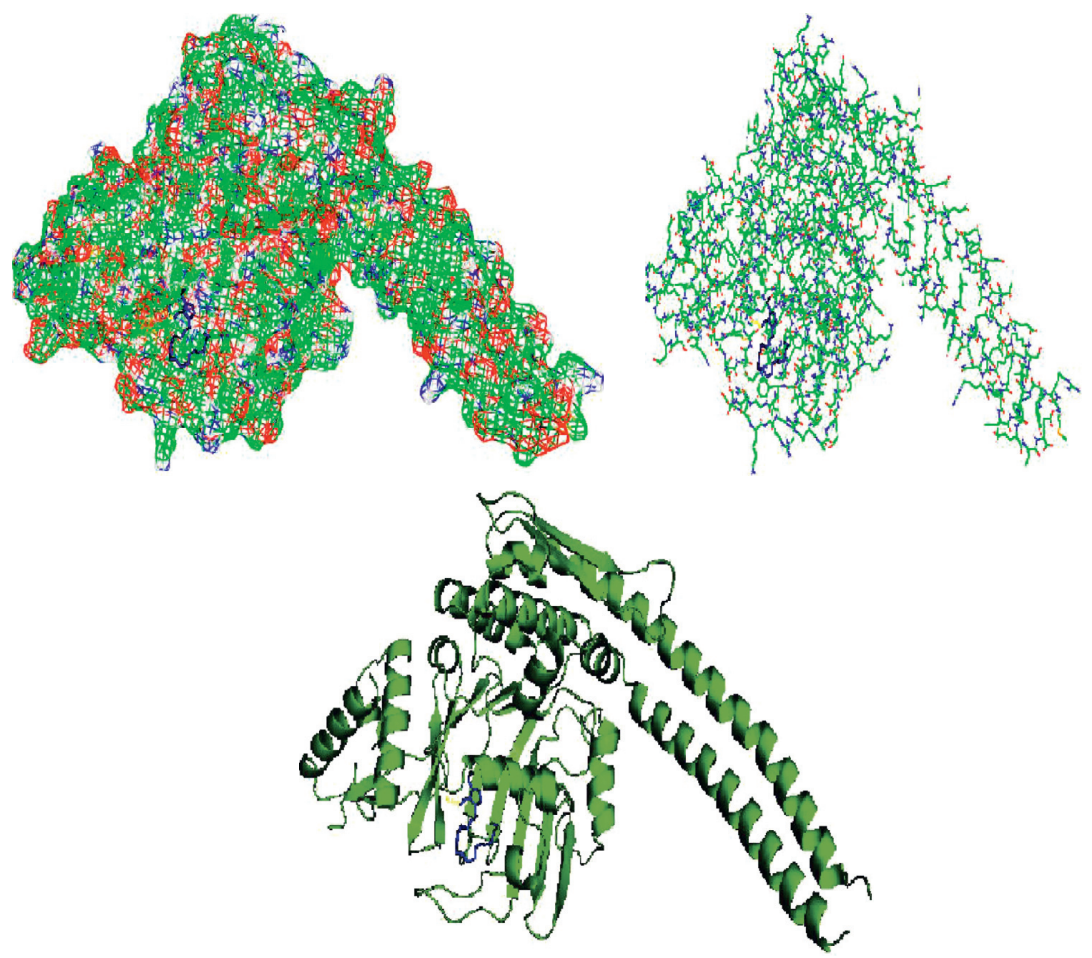

FIgURE 7: Three-dimensional plot of interaction of triazole ligand with B. subtilis (5 h67) receptor.
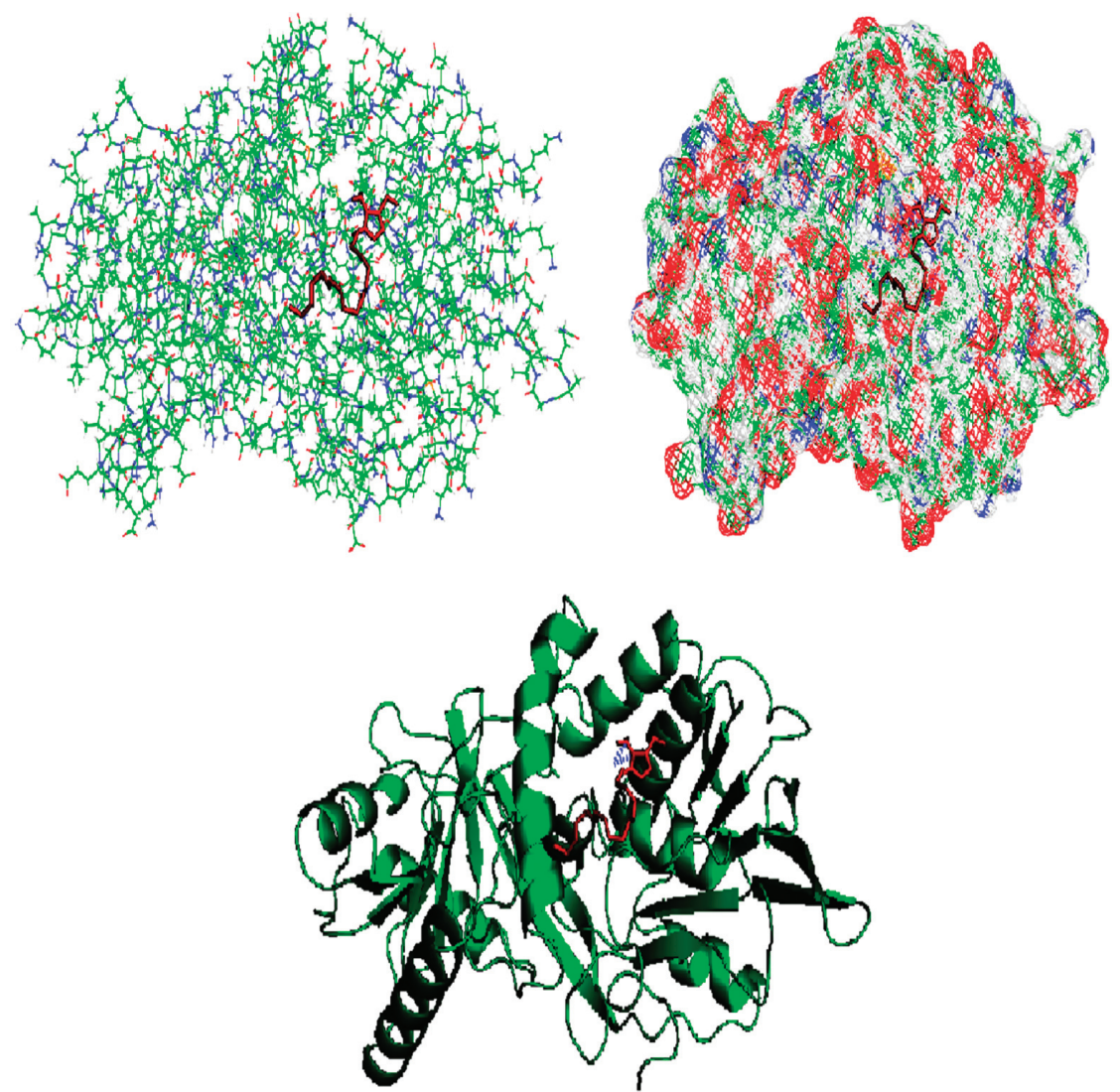

FIgURE 8: Three-dimensional plot of interaction of triazole ligand with P. vulgaris (5i39) receptor. 
these complexes as drug agents in several widespread diseases originated by septicemia, E. coli, e.g., diarrhea, vomiting urinary tract infectivity, and infections obtained from hospitals [46].

3.9. Molecular Docking. Antimicrobial features of drugs were explained using AutoDock tools. The triazole ligand (guest) executed had diverse peptide receptors from host: $E$. coli (3 t88), B. subtilis (5 h67), and P. vulgaris (5i39) by molecular docking (Figures 6-8). The space and energies since most excellent type designed for docking method was examined. Along with computation, a sturdy communication through all receptors having comparable results was illustrated using $\mathrm{HB}$ plots (Figures 6-8). This indicated mutable competence for the H-bonding contact via multicentral groups internal docking complexes. All proteins have inter-hydrogen bonding $[47,48]$. The docking process was evidenced using $2 \mathrm{D}$ plots (Figures 6-8). Therefore, the triazole-thiol ligand interrelated with AA (amino acids) of proteins via $-\mathrm{H}$ bonding as follows.

In case of B. subtilis (5h67), amino acid from protein responded to ligand by hydrogen bonding through 5h67$\mathrm{A} / \mathrm{GlY}^{\prime} 34 / \mathrm{O}$ (bond length $=2.8 \AA$ Á) with binding energy $=-4.9 \mathrm{kcal} \cdot \mathrm{mol}^{-1}$. In case of E. coli ( $\left.3 \mathrm{t} 88\right)$, amino acid from protein responded to ligand by hydrogen bonding of 3 t $88-\mathrm{A} / \mathrm{ASP}^{\prime} 66 / \mathrm{ODl}$ (bond length $=3.4 \AA$ ), $3 \mathrm{t} 88-\mathrm{A} / \mathrm{ASP}^{\prime} 62 / \mathrm{ODl}$ (bond length $=2.2 \AA \hat{\mathrm{A}}$ ) and $3 \mathrm{t} 88-\mathrm{A} /$ $\mathrm{ASP}^{\prime} 62 / \mathrm{OD} 2$ (bond length $=2.6 \mathrm{~A}$ ) with binding energy $=-3.5 \mathrm{kcal} \cdot \mathrm{mol}^{-1}$.

As in case of P. vulgaris (5i39), amino acid from protein responded to ligand by hydrogen bond of 5i39-A/GIU'448/ 0E2 (bond length $=3.5 \AA$ ) and $5 \mathrm{i} 39-\mathrm{A} / \mathrm{GlU}^{\prime} 448 / 0 \mathrm{E} 2$ (bond length $=3.5 \AA$ ) with binding energy $=-3.8 \mathrm{kcal} \cdot \mathrm{mol}^{-1}$.

\section{Conclusions}

Structural and molecular properties of triazole-thiol (HL) toward the transition metal ions, namely, $\mathrm{Fe}(\mathrm{III}), \mathrm{Co}(\mathrm{II})$, $\mathrm{Cu}(\mathrm{II}), \mathrm{Cd}(\mathrm{II})$, and $\mathrm{Ni}(\mathrm{II})$, have been studied by elemental analyses, magnetic measurements, electronic spectra, FT-IR, ${ }^{1} \mathrm{H}-\mathrm{NMR}$, and thermal analyses (TGA and DTA). The interpretation of all thermal decomposition stages has been evaluated. All computations were carried out using Gaussian $09 \mathrm{~W}$ software package. The molecular geometry for the triazole-thiol ligand and its metal chelates was fully optimized using density functional theory B3LYP method. The ligand and its metal complexes have been examined against Escherichia coli, Proteus vulgaris, Bacillus subtilis, and Staphylococcus pyogenes. The complexes with $\mathrm{Co}(\mathrm{II}), \mathrm{Ni}(\mathrm{II})$, and $\mathrm{Cu}(\mathrm{II})$ ions as the metal center exhibited superior activity against both Gram-positive and Gram-negative bacteria to that of standard. In order to assess their antimicrobial potential and molecular docking, AutoDock tools were utilized.

\section{Data Availability}

The data used to support the findings of this study are available from the corresponding author upon request.

\section{Conflicts of Interest}

The authors declare that there are no conflicts of interest regarding the publication of this paper.

\section{Acknowledgments}

The authors wish to articulate their thanks and gratefulness to the Chemistry Department in Taibah University, Cairo University, and National Research Center.

\section{Supplementary Materials}

Table S1: the calculated quantum chemical parameters of the ligand. Table S2: selected geometric atomic charges, bond angles, and bond length of the ligand. Table S3: selected geometric dihedral bond angles $\left(^{\circ}\right)$ of the ligand. (Supplementary Materials)

\section{References}

[1] K. Liu, X. Zhu, J. Wang, B. Li, and Y. Zhang, "Four co-ordination polymers derived from 4-amino-3,5-bis(3-pyridyl)1,2,4-triazole and copper sulfate," Inorg. Chem. Commun.vol. 13, pp. 976-980, 2010.

[2] Q.-G. Zhai, M.-C. Hu, Y. Wang, W.-J. Ji, S.-N. Li, and Y.-C. Jiang, "Synthesis and characterizations of a novel diatype Ag-BPT coordination polymer with tetranu- clear motifs as jointing points (BPT=3,5-bis(3-pyridyl)- 1,2,4-triazole," Inorganic Chemistry Communications, vol. 12 , no. 4, pp. 286-289, 2009.

[3] Y. L. N. Murthy, B. Govindh, B. S. Diwakar, K. Nagalakshmi, and K. V. R. Rao, "Synthesis and bioevaluation of Schiff and Mannich bases of isatin derivatives with 4-amino-5-benzyl2,4-dihydro-3H-1,2,4-triazole-3-thione," Medicinal Chemistry Research, vol. 21, no. 10, pp. 3104-3110, 2012.

[4] M. Kumasaki, K. Sasahara, and Y. Nakajima, "Thermal sensitivities of triazole derivatives and dinitrobenzene mixtures from the perspective of charge transfer," Journal of Thermal Analysis and Calorimetry, vol. 125, no. 1, pp. 331-338, 2016.

[5] M. M. H. Khalil, E. H. Ismail, G. G. Mohamed, E. M. Zayed, and A. B. Kame, "Transitions metal complexes derived from natural schiff bases for determinations of (III) spectrophotometrically in natural water," Chinese Journal of Inorganic Chemistry, vol. 28, pp. 1001-4861, 2012.

[6] P. R. Dametto, B. Ambrozini, F. J. Caires, V. P. Franzini, and M. Ionashiro, "Synthesis, characterization and thermal behaviour of solid-state compounds of folates with some bivalent transition metals ions," Journal of Thermal Analysis and Calorimetry, vol. 115, no. 1, pp. 161-166, 2014.

[7] I. Ledeţi, G. Vlase, T. Vlase, V. Bercean, and A. Fuliaş, "Kinetic of solid-state degradation of transitional coordinative compounds containing functionalized 1,2,4-triazolic ligand," Journal of Thermal Analysis and Calorimetry, vol. 121, no. 3, pp. 1049-1057, 2015.

[8] M. K. Bharty, S. Paswan, R. K. Dani et al., "Polymeric Cd(II), trinuclear and mononuclear Ni(II) complexes of 5- methyl-4phenyl-1,2,4-triazole-3-thione: synthesis, structural characterization, thermal behaviour, fluorescence properties and antibacterial activity," Journal of Molecular Structure, vol. 1130, pp. 181-193, 2017.

[9] E. M. Zayed, M. A. Zayed, and M. El-Desawy, "Preparation and structure investigation of novel Schiff bases using 
spectroscopic, thermal analyses and molecular orbital calculations and studying their biological activities," Spectrochimica Acta Part A: Molecular and Biomolecular Spectroscopy, vol. 134, pp. 155-164, 2015.

[10] L. Calu, M. Badea, M. C. Chifiriuc et al., "Synthesis, spectral, thermal, magnetic and biological characterization of $\mathrm{Co}(\mathrm{II})$, $\mathrm{Ni}(\mathrm{II}), \mathrm{Cu}(\mathrm{II})$ and $\mathrm{Zn}(\mathrm{II})$ complexes with a Schiff base bearing a 1,2,4-triazole pharmacophore," Journal of Thermal Analysis and Calorimetry, vol. 120, no. 1, pp. 375-386, 2015.

[11] E. M. Zayed and M. A. Zayed, "Synthesis of novel Schiff's bases of highly potential biological activities and their structure investigation," Spectrochimica Acta Part A: Molecular and Biomolecular Spectroscopy, vol. 143, pp. 81-90, 2015.

[12] G. G. Mohamed, E. M. Zayed, and A. M. M. Hindy, "Coordination behavior of new bis Schiff base ligand derived from 2 -furan carboxaldehyde and propane-1,3-diamine. Spectroscopic, thermal, anticancer and antibacterial activity studies," Spectrochimica Acta Part A: Molecular and Biomolecular Spectroscopy, vol. 145, pp. 76-84, 2015.

[13] L. Calu, M. Badea, D. Falcescu, D. Duca, D. Marinescu, and R. Olar, "Thermal study on complexes with Schiff base derived from 1,2,4-triazole as potential antimicrobial agents," Journal of Thermal Analysis and Calorimetry, vol. 111, no. 3, pp. 1725-1730, 2013.

[14] M. Badea, L. Calu, M. C. Chifiriuc et al., "Thermal behaviour of some novel antimicrobials based on complexes with a Schiff base bearing 1,2,4-triazole pharmacophore," Journal of Thermal Analysis and Calorimetry, vol. 118, no. 2, pp. 11451157, 2014.

[15] M. M. H. Khalil, E. H. Ismail, G. G. Mohamed, E. M. Zayed, and A. Badr, "Synthesis and characterization of a novel Schiff base metal complexes and their application in determination of iron in different types of natural water," Open Journal of Inorganic Chemistry, vol. 2, no. 2, pp. 13-21, 2012.

[16] J.-C. Chen, A.-J. Zhou, S. Hu, M.-L. Tong, and Y.-X. Tong, "Synthesis, structure and magnetic property of a new mixedvalence copper(I/II) complex derived from 3,5-bis(pyridin-2yl)-1,2,4-triazole," Journal of Molecular Structure, vol. 794, no. $1-3$, pp. 225-229, 2006.

[17] M. H. Klingele and S. Brooker, "From N-substituted thioamides to symmetrical and unsymmetrical 3,4,5-trisubstituted 4H-1,2,4-triazoles: synthesis and characterisation of new chelating ligands," European Journal of Organic Chemistry, vol. 16, pp. 3422-3434, 2004.

[18] J.-J. Liu, X. He, M. Shao, and M.-X. Li, "Syntheses, structures and thermal stabilities of four complexes with 4-amino-3,5bis(3-pyridyl)-1,2,4-triazole ligand," Journal of Molecular Structure, vol. 891, no. 1-3, pp. 50-57, 2008.

[19] A. I. Matesanz, C. Pastor, and P. Souza, "Synthesis and structural characterization of a disulphide-bridged tetranuclear palladium(II) complex derived from 3,5-diacetyl 1,2,4triazole bis(4-ethylthiosemicarbazone)," Inorganic Chemistry Communications, vol. 10, no. 1, pp. 97-100, 2007.

[20] X.-F. Xie, S.-P. Chen, Z.-Q. Xia, and S.-L. Gao, "Construction of metal-organic frameworks with transitional metals based on the 3,5-bis(4-pyridyl)-1H-1,2,4-triazole ligand," Polyhedron, vol. 28, no. 4, pp. 679-688, 2009.

[21] X. He, J. J. Liu, H. M. Guo, M. Shao, and M. X. Li, "Syntheses, topological networks and properties of four complexes based on 4-amino-3,5-bis(3-pyridyl)-1,2,4-triazole ligand," Polyhedron, vol. 29, no. 3, pp. 1062-1068, 2010.

[22] T. W. Kajdan, P. J. Squattrito, and S. N. Dubey, "Coordination geometries of bis(4-amino-3-ethyl-1,2,4-triazole- 5-thione) complexes of $\mathrm{Mn}, \mathrm{Fe}, \mathrm{Co}, \mathrm{Ni}, \mathrm{Cu}$ and $\mathrm{Zn}$ : relationship to the 3methyl analogs," Inorganica Chimica Acta, vol. 300-302, pp. 1082-1089, 2000.

[23] M. J. Frisch, G. W. Trucks, H. B. Schlegel et al., Gaussian 9, Revision D, Gaussian Inc., Wallingford, CT, USA, 2010.

[24] R. Dennington, T. Keith, and J. Millam, GaussView, Version 4.1.2, Semichem Inc., Shawnee Mission, KS, USA, 2007.

[25] Halgren T. A., J. Comput. Chem. 1998, 17, 490.

[26] G. M. Morris, D. S. Goodsell, R. S. Halliday et al., "Automated docking using a Lamarckian genetic algorithm and an empirical binding free energy function," Journal of Computational Chemistry, vol. 19, no. 14, pp. 1639-1662, 1998.

[27] F. J. Solis and R. J.-B. Wets, "Minimization by random search techniques," Mathematics of Operations Research, vol. 6, no. 1, pp. 19-30, 1981.

[28] H. A. A. El Salam, E. M. A. Yakout, M. A. El-Hashash, and G. A. M. Nawwar, "Facile synthesis of 6-(heptadec-8-enyl) thiopyrimidines incorporating glycosyl moiety and their antitumor activity," Monatshefte für Chemie, vol. 144, no. 12, pp. 1893-1901, 2013.

[29] H. A. A. El Salam, E. M. A. Yakout, G. A. M. Nawwar, M. A. El-Hashash, and A. T. H. Mossa, "Synthesis of some new 1,2,4-triazoles containing olyl moiety and evaluation of their antimicrobial and antioxidant activities," Monatshefte für Chemie, vol. 148, no. 2, pp. 291-304, 2017.

[30] E. M. Zayed, M. A. Zayed, and A. M. M. Hindy, “Thermal and spectroscopic investigation of novel Schiff base, its metal complexes, and their biological activities," Journal of Thermal Analysis and Calorimetry, vol. 116, no. 1, pp. 391400, 2014.

[31] E. M. Zayed, G. G. Mohamed, and A. M. M. Hindy, "Transition metal complexes of novel Schiff base," Journal of Thermal Analysis and Calorimetry, vol. 120, no. 1, pp. 893903, 2015.

[32] M. T. Rakesh, S. M. Tushar, B. G. Mitesh, and K. S. Manish, "Synthesis and characterization of $\mathrm{Cu}(\mathrm{II}), \mathrm{Ni}(\mathrm{II})$ and $\mathrm{Co}(\mathrm{II})$ based 1,4-substituted thiosemicarbazone complexes," Chemical Science Transactions, vol. 2, no. 1, pp. 135-140, 2013.

[33] E. M. Zayed, E. H. Ismail, G. G. Mohamed, M. M. H. Khalil, and A. B. Kamel, "Synthesis, spectroscopic and structural characterization, and antimicrobial studies of metal complexes of a new hexadentate Schiff base ligand. Spectrophotometric determination of $\mathrm{Fe}(\mathrm{III})$ in water samples using a recovery test," Monatshefte für Chemie-Chemical Monthly, vol. 145, no. 5, pp. 755-765, 2014.

[34] W. H. Mahmoud, G. G. Mohamed, and N. F. Mahmoud, "New bioactive $\mathrm{Pt}(\mathrm{II})$ binary and ternary metal complexes with guaifenesin drug: synthesis, geometrical structure, and spectroscopic and thermal characterization," Applied Organometallic Chemistry, vol. 31, no. 4, p. e3583, 2017.

[35] R. Olar, L. Calu, M. Badea et al., "Thermal behaviour of some biologically active species based on complexes with a triazolopyrimidine pharmacophore," Journal of Thermal Analysis and Calorimetry, vol. 127, no. 1, pp. 685-696, 2017.

[36] L. Calu, M. Badea, R. C. Korošec et al., "Thermal behaviour of some novel biologically active complexes with a triazolopyrimidine pharmacophore," Journal of Thermal Analysis and Calorimetry, vol. 127, no. 1, pp. 697-708, 2017.

[37] M. M. Deshpande, I. H. Seema, and P. A. Kulkarni, "Preparation, physical characterization and antimicrobial evaluation of $\mathrm{Co}(\mathrm{II}), \mathrm{Ni}(\mathrm{II})$ and $\mathrm{Fe}(\mathrm{III})$ complexes of heterocyclic Schiff bases," International Journal of Biological \& Pharmaceutical Research, vol. 4, no. 6, pp. 460-464, 2013. 
[38] E. M. Zayed, H. H. Sokker, H. M. Albishri, and A. M. Farag, "Potential use of novel modified fishbone waste for anchoring hazardous metal ions wastes from their solutions," Ecological Engineering, vol. 61, pp. 390-393, 2013.

[39] W. H. Mahmoud, G. G. Mohamed, and A. M. Refaat, "Preparation, characterization, biological activity, density functional theory calculations and molecular docking of chelates of diazo ligand derived from $\mathrm{m}$-phenylenediamine and p-chlorophenol," Applied Organometallic Chemistry, vol. 31, no. 11, p. e3753, 2017.

[40] W. H. Mahmoud, F. N. Sayed, and G. G. Mohamed, "Synthesis, characterization and in vitro antimicrobial and antibreast cancer activity studies of metal complexes of novel pentadentate azo dye ligand," Applied Organometallic Chemistry, vol. 30, no. 11, pp. 959-973, 2016.

[41] M. Badea, F. Pătraşcu, R. Cerc Korošec et al., "Thermal, spectral, magnetic and biologic characterization of new $\mathrm{Ni}(\mathrm{II})$, $\mathrm{Cu}(\mathrm{II})$ and $\mathrm{Zn}$ (II) complexes with a hexaazamacro cyclic ligand bearing ketopyridine moieties," Journal of Thermal Analysis and Calorimetry, vol. 118, no. 2, pp. 1183-1193, 2014.

[42] W. M. I. Hassan, E. M. Zayed, A. K. Elkholy, H. Moustafa, and G. G. Mohamed, "Spectroscopic and density functional theory investigation of novel schiff base complexes," Spectrochimica Acta Part A: Molecular and Biomolecular Spectroscopy, vol. 103, pp. 378-387, 2013.

[43] W. H. Mahmoud, F. N. Sayed, and G. G. Mohamed, "Azo dye with nitrogen donor sets of atoms and its metalcomplexes: synthesis, characterization, DFT, biological, anticancer and molecular docking studies," Applied Organometallic Chemistry, vol. 32, no. 6, p. e4347, 2018.

[44] A. S. Al-Bogami, T. S. Saleh, and E. M. Zayed, "Divergent reaction pathways for one-pot, three-component synthesis of novel $4 \mathrm{H}$-pyrano[3,2-h] quinolines under ultrasound irradiation," Ultrasonics Sonochemistry, vol. 20, no. 5, pp. 11941202, 2013.

[45] W. H. Mahmoud, R. G. Deghadi, and G. G. Mohamed, "Novel Schiff base ligand and its metal complexes with some transition elements. Synthesis, spectroscopic, thermal analysis, antimicrobial and in vitro anticancer activity," Applied Organometallic Chemistry, vol. 30, no. 4, pp. 221-230, 2016.

[46] R. S. Corrêa, M. M. da Silva, A. E. Graminha et al., "Ruthenium(II) complexes of 1,3-thiazolidine-2-thione: cytotoxicity against tumor cells and antiTrypanosoma cruzi activity enhanced upon combination with benznidazole," Journal of Inorganic Biochemistry, vol. 156, pp. 153-163, 2016.

[47] E. M. Zayed, A. M. M. Hindy, and G. G. Mohamed, "Molecular structure, molecular docking, thermal, spectroscopic and biological activity studies of bis-Schiff base ligand and its metal complexes," Applied Organometallic Chemistry, vol. 32, no. 1, p. e3952, 2017.

[48] W. H. Mahmoud, N. F. Mahmoud, and G. G. Mohamed, "Synthesis, physicochemical characterization, geometric structure and molecular docking of new biologically active ferrocene based Schiff base ligand with transition metal ions," Applied Organometallic Chemistry, vol. 31, no. 12, Article ID e3858, 2017. 